\title{
A Non-chemical Approach to the Management of Root Rot Disease Complex of Tomato Concomitantly Caused by Rhizoctonia solani and Meloidogyne javanica
}

Aradhna Sagwal, Satish Kumar, Kushal Raj

10.18805/IJARe.A-5807

\begin{abstract}
Background: Tomato (Solanum lycopersicum L.) is an important vegetable crop not only for its economic importance but also for its nutritional value. It remained prone to various diseases and amongst them, root rot disease complex caused by concomitant occurrence of $R$. solani and $M$. javanica has been key problem in Haryana resultantly reduces yield and production to great extent.

Methods: Present study was carried out with the aim to evaluate the effect of organic amendments and biocontrol agents on root rot disease complex in tomato cv. Hisar Arun (Selection 7). Tomato seeds were sown @ 10 seeds/pot filled with sterilized sandy loam soil having $1000 \mathrm{mg} / \mathrm{kg}$ soil (Rhizoctonia solani inoculum level) and $1000 \mathrm{~J} 2 / \mathrm{kg}$ soil (M. javanica inoculum level).

Result: The minimum mortality of 33.3 and 36.6 per cent was observed when the soils were incorporated with mustard cake @ 2g/ $\mathrm{kg}$ soil followed by cotton cake @ 2g/kg soil in comparison to total mortality of 63.3 per cent in control pots and the soil application of mustard cake protected 47.4 per cent plants from mortality. The application of Glomus mosseae (VAM) at 200, 150,100 sporocarps/ $\mathrm{kg}$ soil managed disease to the extent of $36.8 \% 21.0 \%$ and $10.4 \%$ respectively. Incorporation of $T$. harzianum@ $5 \mathrm{~g} / \mathrm{kg} \mathrm{soil} \mathrm{and} 10 \mathrm{~g} /$ $\mathrm{kg}$ soil managed the disease to the extent of $21 \%$ and $42 \%$ respectively. The minimum mortality of $33.3 \%$ was recorded when seeds were dressed with Carbendazim 50WP whereas 36.6 per cent with Carboxin 37.5WP + Thiram 37.5WP in comparison to 63.3 per cent in control pots. Systemic approach to manage the root-rot disease complex with the help of organic amendments, bioagents and fungicides can prevent the losses caused to the crop.

Key words: Carbendazim, Glomus mosseae, Meloidogyne javanica, Organic amendments, Rhizoctonia solani, Tomato, Trichoderma harzianum
\end{abstract}

\section{INTRODUCTION}

Tomato (Solanum lycopersicum L.) is an important vegetable crop not only for its economic importance but also for its nutritional value. India ranks second in the area as well as production of tomato after China. In India andhra Pradesh ranked first for tomato production (Rizvi et al., 2015 b). The estimated production of tomato in India is about 19.759 Lakh MT with productivity of $25.04 \mathrm{MT} /$ ha and Haryana contributed 7.53 Lakh MT with productivity of $21.54 \mathrm{MT} / \mathrm{ha}$ (www. indiastat. com). The productivity of tomato in India is comparatively lower than many other countries, presumably due to disease prevalence, improper and inadequate supply of nutrients and lack of adoption of new improved production technologies. Tomato is prone to attack by fungal, bacterial, nematode and viral diseases and among biotic stresses rootrot disease complex caused by concomitant occurrence of $R$. solani and M. javanica has been key problem and leads to more severe damage in tomato than their individual effect. (Kumar and Haseeb 2009).

Root rot complex caused by Rhizoctonia solani and Meloidogyne javanica is considered as destructive disease of nursery as well as transplanted crop of tomato. Rhizoctonia solani causes pre-emergence and postemergence plant mortality in seedlings, black lesions in root and stem rot. The disease is characterized as complete rotting of seeds or rotting of emerging radical before it come
Department of Plant Pathology, College of Agriculture, Chaudhary Charan Singh Haryana Agricultural University, Hisar-125 004, Haryana, India.

Corresponding Author: Kushal Raj, Department of Plant Pathology, College of Agriculture, Chaudhary Charan Singh Haryana Agricultural University, Hisar-125 004, Haryana, India.

Email: kushalraj@hau.ac.in

How to cite this article: Sagwal, A., Kumar, S. and Raj, K. (). A Non-chemical Approach to the Management of Root Rot Disease Complex of Tomato Concomitantly Caused by Rhizoctonia solani and Meloidogyne javanica. Indian Journal of Agricultural Research. DOI: $10.18805 /$ IJARe.A-5807.

Submitted: 28-04-2021 Accepted: 26-07-2021 Online: 21-08-2021

and out at ground level, these symptoms are grouped as pre-emergence while in post-emergence, there is breakdown of host cell walls by pectinase enzyme and the lesion increases in size more towards downward than upward and the root tissues disintegrate at the latter stages resultantly the bark wither away. The sclerotia produced by fungus are barrel shaped and clearly visible on the surface of infected roots. The lower leaves start drying from lower parts of the plant and entire plant get dried off prematurely, whereas, other symptoms are stunting, yellowing, defoliation and premature death of plants in severe form particularly when 
in combination with nematode, hence, the pernicious effects of $R$. solani become more pronounced in the presence of M. incognita (Abuzar, 2013).

It is much difficult to manage Rhizoctonia solaniby virtue of its presence in soil or plant debris, polyphagous nature and its vast distribution. The association of Meloidogyne sp. makes the situation more complex for successful economical control of root rot disease complex of tomato. It is quite difficult to manage the disease complex through chemicals alone. Fungicides and nematicides both being costly have undesirable effect on the environment when applied regularly; encourage development of resistance in pathogen. In addition to the target pest, they are harmful to the beneficial micro-organisms in the rhizosphere, contaminate soil, water and accumulate in plant parts (Rizvi et al., 2015 b). There is a need to explore and exploit other methods for disease management in an integrated manner. The present study was carried to find out the effect of organic amendments, fungicides and biocontrol agents on root rot disease complex of tomato (Solanum lycopersicum L.) caused by concomitant occurrence of Rhizoctonia solani and Meloidogyne javanica.

\section{MATERIALS AND METHODS}

The present study was carried out in Department of Plant Pathology, Chaudhary Charan Singh Haryana Agricultural University, Hisar during 2018-19. The experiment was conducted on most popular and moderately resistant variety Hisar Arun (Selection 7).

Two bio control agents viz. Glomus mosseae, vesicular arbuscular mycorrhiza (VAM) and Trichoderma harzianum were applied in sandy loam soil for evaluation against $R$. solani and $M$. javanica causing root rot disease complex in tomato. These biocontrol agents were thoroughly mixed in each pot seven days before sowing in soil.

The vesicular-arbuscular mycorrhizal fungus viz. Glomus mosseae procured from Department of Plant Pathology, CCS HAU, Hisar was raised and maintained in earthen pots of $30 \mathrm{~cm}$ diameter having $5 \mathrm{~kg}$ sterilized sand on wheat (Triticum aestivum) and pearl millet (Pennisetum typhoides). one hundred gram inoculum of mycorrhizal fungus having 450-500 extramatrical chlamydospores was incorporated in upper $5 \mathrm{~cm}$ soil layer per pot and then ten seeds of wheat or pearl millet per pot were sown. The pots were irrigated regularly. The shoot portions of the growing plants were cut at soil level after 90 days and soil in pots was left undisturbed to get air dried. The soil was fragmented into small particles and rootlets cut into $1 \mathrm{~cm}$ pieces. The mixture of soil and root segments was used as inoculum.

\section{Extraction of sporocarps from soil}

The sporocarps were extracted by wet sieving and decantation technique (Gerdemann and Nicolson, 1963). $250 \mathrm{~g}$ of soil was suspended in one liter of water two hundred fifty heavier particles were allowed to settle down for $30 \mathrm{~min}$ and the liquid was decanted through 20 mesh sieve, fine enough to remove larger particles or organic material but coarse enough to allow the desired sporocarps to pass through. The sieved suspension was stirred to resuspend all the particles. The heavier particles were allowed to settle down for $10 \mathrm{~min}$ and the suspension was then passed through a 60-mesh sieve. Resultant suspension was sieved serially through 100, 150, 200 and 240 mesh sieves. The maximum sporocarps were retained on 100 mesh sieve. These sporocarps were washed 2-3 times with water in order to free them from soil and organic material. The volume was made to $50 \mathrm{ml}$ and one $\mathrm{ml}$ of this spore suspension taken in a watch glass was examined under stereoscopic microscope for sporocarps count. The VAM was used at three different doses viz. 100, 150 and 200 sporocarps per $\mathrm{kg}$ soil based on the criteria of Borah et al. (2018).

The culture of $T$. harzianum was procured from the Dept. of Plant Pathology, CCS HAU, Hisar and maintained on wheat bran saw dust medium (WBSD). For this wheat bran, saw dust and water (WBSD) (3:1:3.5 w/w/v) were mixed thoroughly, filled in a polypropylene bag $(100 \mathrm{~g} / \mathrm{bag})$, sealed on flame and autoclaved at $15 \mathrm{lbs}$ pressure per square inch for 30 minutes for two consecutive days (Mukhopadhyay et al., 1986). The sterilized bags were inoculated separately with the three days old culture of $T$. harzianum under aseptic conditions and incubated at $25 \pm 2^{\circ} \mathrm{C}$ for about 10 days. The bags were shaken thoroughly at three days' interval to allow the uniform growth in the bag till 10 days. Two different treatments viz. 5 and $10 \mathrm{~g} / \mathrm{kg}$ soil of $T$. harzianum were tested against root rot disease complex of tomato.

The culture of root knot nematode Meliodogyne javanica was collected from tomato plants showing galling and multiplied on tomato crop. The egg masses were collected from roots by using forceps and transferred to double fold tissue paper put on molded pieces of aluminium wire net plated in Petri plates. Egg masses were submerged in plates by adding sufficient amount of water. The water containing $\mathrm{J}_{2}$ larvae was collected next day and hatched $\mathrm{J}_{2}$ larvae were used as pathogen inoculum.

Earthen pots of $15 \mathrm{~cm}$ diameter were filled with sterilized sandy loam soil (autoclaved at 22 psi for $2 \mathrm{~h}$ ). The inocula were added @ 1000 mg/kg soil (Rhizoctonia solani inoculum level) and @ $1000 \mathrm{~J}_{2} / \mathrm{kg}$ soil of $M$. javanica The inocula were mixed thoroughly upto $5 \mathrm{~cm}$ depth of the pot. Tomato seeds were sown in the pots @10seeds/pot immediately after adding the inocula.

\section{Effect of organic amendments on root rot disease complex of tomato}

The organic amendments viz. farm yard manure, poultry manure, spent mushroom compost@ $5 \mathrm{~g} / \mathrm{kg}$ soil and vermicompost, cotton cake, mustard cake, neem cake @ $2 \mathrm{~g} / \mathrm{kg}$ soil were thoroughly mixed in each pot.

\section{Effect of seed dressing of fungicides on root rot disease complex of tomato}

The seeds were dressed with five different fungicides viz., Carbendazim 50WP, Captan 50WP, Thiram 75WP, 
Mancozeb 75WP, Carboxin 37.5WP +Thiram 37.5WP @ $2.0 \mathrm{~g} / \mathrm{kg}$ seed against root-rot disease complex causing pathogens Rhizoctonia solani and Meloidogyne javanica in tomato cv. Hisar Arun (Selection 7).

Untreated seeds sown in inoculated and uninoculated soils served as checks. The check without any pathogen inoculum was also maintained to compare the seeds germination. The pots were irrigated at regular interval to maintain proper moisture level. Observations were recorded on per cent pre-emergence and post-emergence mortality (30 DAS) for all the treatments.

Per cent plant mortality $=100$

Plants stand in inoculated treatment $\times 100$

The explants stand in uningcylated control $\times$ mpletely randomized design (CRD) with three replications for all treatments under screen house conditions. Statistical analysis was carried out through opstat (https:// www.hau.ac.in/page/o-p-stat).

\section{RESULTS AND DISCUSSION}

Effect of different organic amendments on root rot disease complex of tomato

The application of organic amendments increases population of resident bacteria and fungi which decrease the disease incidence of $R$. solani (Cohen et al., 2005). The application of organic amendments improves the soil and plant health that in turn reduces the disease incidence. Organic manures increase the water holding capacity, porosity and soil aeration thus help in rapid root extension and improved plant vigour. The results regarding effect of soil incorporation of six organic amendments on root rot disease complex of tomato are presented in Table 1. Minimum mortality of 33.3 per cent was recorded when mustard cake was used as organic amendment followed by cotton cake with $36.6 \%$ total mortality as compared to the highest mortality of 63.3 per cent in control pots ( $R$. solani and $M$. javanica inoculated simultaneously). Application of mustard cake could manage disease by 47.4 per cent, that was 42.2 and 42.0 per cent with cotton cake and vermicompost.

Soil application of four organic amendments viz., mustard cake, cotton cake, vermicompost and neem cake significantly reduced pre-emergence plant mortality as compared to control in which no soil application of organic amendments were done, whereas, all the seven organic amendments significantly decreased post-emergence plant mortality as compared to control. The disease control on amendment with neem cake, spent mushroom compost, FYM and poultry manure was 31.6, 26.2, 26.2 and $10.6 \%$ respectively, as compared to control. The findings of present work are in corroboration with those of other investigations. Rizvi et al. (2015 a), Shafique et al. (2015), Choudhary and Ashraf (2019) and Parveen et al. (2019) also observed that organic amendments reduced the root rot disease complex in tomato.

\section{Effect of different concentrations of Glomus mosseae (VAM) on root rot disease complex of tomato}

The per cent disease control was directly proportional to the concentration of VAM (Table 2). A maximum of $36.8 \mathrm{per}$ cent disease control was recorded with soil application of 200 sporocarps $/ \mathrm{kg}$ soil followed by 21 per cent disease control by soil application of 150 sporocarps $/ \mathrm{kg}$ soil and least disease control of 10.4 per cent was recorded at 100 sporocarps/kg soil.

Table 1: Effect of different organic amendments on root rot disease complex of tomato cv. Hisar Arun (Selection 7) under screen house conditions

\begin{tabular}{|c|c|c|c|c|}
\hline \multirow{2}{*}{ Organic amendments } & \multicolumn{2}{|c|}{${ }^{*}$ Disease Incidence } & \multirow{2}{*}{$\begin{array}{c}\text { Total } \\
\text { mortality (\%) }\end{array}$} & \multirow{2}{*}{$\begin{array}{l}\text { Disease } \\
\text { control (\%) }\end{array}$} \\
\hline & ${ }^{1}$ PEM & ${ }^{2} \mathrm{POEM}$ & & \\
\hline FYM & $20.0(26.6)$ & $26.7(31.0)$ & 46.7 & 26.2 \\
\hline Poultry manure & $23.3(28.8)$ & $33.3(35.2)$ & 56.6 & 10.6 \\
\hline Spent mushroom compost & $20.0(26.6)$ & $26.7(31.0)$ & 46.7 & 26.2 \\
\hline Vermicompost & $16.7(23.9)$ & $20.0(26.6)$ & 36.7 & 42.0 \\
\hline Cotton cake & $13.3(21.1)$ & $23.3(28.8)$ & 36.6 & 42.2 \\
\hline Mustard cake & $10.0(18.4)$ & $23.3(28.8)$ & 33.3 & 47.4 \\
\hline Neem cake & $13.3(21.1)$ & $30.0(33.2)$ & 43.3 & 31.6 \\
\hline $\begin{array}{l}\text { Check-1(R. Solani and } M \text {. javanica } \\
\text { inoculated simultaneously) }\end{array}$ & $23.3(28.8)$ & $40.0(39.2)$ & 63.3 & 0.0 \\
\hline Check-2(No pathogen) & $0.0(4.05)$ & $0.0(4.05)$ & 0.0 & - \\
\hline CD at $5 \%$ & $(5.6)$ & $(4.9)$ & - & - \\
\hline CV & (14.7) & $(9.8)$ & & \\
\hline $\mathrm{SE}(\mathrm{m})$ & $(1.9)$ & $(1.6)$ & & \\
\hline
\end{tabular}

*(Mean of 3 replications)

Figures in parentheses are angular transformed values

${ }^{1} \mathrm{PEM}=$ Pre-emergence mortality ${ }^{2} \mathrm{POEM}=$ Post-emergence mortality 
A Non-chemical Approach to the Management of Root Rot Disease Complex of Tomato Concomitantly Caused by Rhizoctonia...

Pre-emergence plant mortality was $13.3,16.7$ and 20.0 per cent with application of 200, 150, 100 sporocarps/kg soil, respectively as compared to check 1 (23.3 per cent). Post- emergence plant mortality was 26.7 per cent when soil was incorporated with 200 sporocarps $/ \mathrm{kg}$ soil followed by post emergence plant mortality of 33.3 and 36.7 per cent when soil was incorporated with 150 and 100 sporocarps/ $\mathrm{kg}$ soil respectively as compared to control. These observations are in agreement with the findings of Kareem and Hassan (2014), Abo-Korah (2017) and Borah et al. (2018) who also reported that root rot disease complex incidence was significantly suppressed by Glomus mosseae.

Effect of different concentrations of Trichoderma harzianum on root rot disease complex

Root rot disease complex was managed to the extent of 42.0 per cent when $T$. harzianum was applied in the soil $@ 10 \mathrm{~g} / \mathrm{kg}$ soil and that was 21 per cent when T. harzianum was applied in soil @ $5 \mathrm{~g} / \mathrm{kg}$ soil indicating better disease control at higher concentration of $T$. harzianum (Table 3 ).

Pre-emergence mortality was 16.7 per cent when $T$. harzianum was incorporated in soil @ $5 \mathrm{~g} / \mathrm{kg}$ soil and it was reduced significantly to 10.0 per cent when $T$. harzianum was used @ $10 \mathrm{~g} / \mathrm{kg}$ soil, whereas, maximum preemergence mortality of 23.3 per cent was observed in control ( $R$. solani and M. javanica inoculated simultaneously). Postemergence mortality was also reduced to 26.7 per cent at $10 \mathrm{~g} / \mathrm{kg}$ soil as compared to control (40.0 per cent).
The findings of present study are in accordance with results of El-Nagdi and Abd-El-Khair (2008), Archana and Shweta (2014) and Singh et al. (2015) who observed the use of soil incorporation of $T$. harzianum for the management of $R$. solani and $M$. javanica disease complex in various crops.

\section{Effect of seed dressing of fungicides on root rot disease} complex of tomato

All fungicides were found significantly efficient over control in reducing per cent disease incidence 30 days after sowing. A minimum mortality of 33.3 and 36.6 per cent was achieved when seeds were dressed with Carbendazim 50WP and Carboxin 37.5WP + Thiram 37.5WP, respectively as compared to the highest mortality of 63.3 per cent in control pots (Table 4). Carbendazim 50WP provided 47.4 per cent disease control and Carboxin 37.5WP + Thiram 37.5WP protected 42.2 per cent plants from mortality. Thiram 75WP provided 31.6 per cent disease control and least disease control of 10.6 per cent was provided by Mancozeb 75WP as compared to control.

Pre-emergence plant mortality was 16.7 per cent by seed dressing with Captan 50 WP, whereas, pre-emergence plant mortality of 13.3 per cent was observed when seed dressing was done with Carbendazim 50WP and Carboxin 37.5WP + Thiram 37.5WP, however, both the treatments did not differ significantly in reducing pre-emergence plant mortality. There was no significant difference in pre-

Table 2: Effect of different concentrations of Glomus mosseae (VAM) on root rot disease complex of tomato cv. Hisar Arun (Selection 7) under screen house conditions

\begin{tabular}{|c|c|c|c|c|}
\hline \multirow{2}{*}{$\begin{array}{l}\text { Glomus mosseae } \\
\text { (sporocarps / kg soil) }\end{array}$} & \multicolumn{2}{|c|}{${ }^{*}$ Disease incidence } & \multirow{2}{*}{$\begin{array}{c}\text { Total } \\
\text { mortality (\%) }\end{array}$} & \multirow{2}{*}{$\begin{array}{l}\text { Disease } \\
\text { control (\%) }\end{array}$} \\
\hline & PEM & POEM & & \\
\hline 100 & $20.0(26.6)$ & $36.7(37.2)$ & 56.7 & 10.4 \\
\hline 150 & $16.7(23.9)$ & $33.3(35.2)$ & 50.0 & 21.0 \\
\hline 200 & $13.3(21.1)$ & $26.7(31.0)$ & 40.0 & 36.8 \\
\hline $\begin{array}{l}\text { Check } 1 \text { ( } R \text {. solani and } M \text {. javanica } \\
\text { inoculated simultaneously) }\end{array}$ & $23.3(28.8)$ & $40.0(39.2)$ & 63.3 & 0.0 \\
\hline Check 2 (No pathogen) & $0.0(4.05)$ & $0.0(4.05)$ & 0.0 & - \\
\hline$C D$ at $5 \%$ & $(6.3)$ & $(5.1)$ & - & - \\
\hline CV & $(16.4)$ & (9.5) & & \\
\hline SE $(m)$ & $(1.9)$ & $(1.6)$ & & \\
\hline
\end{tabular}

Table 3: Effect of different concentrations of Trichoderma harzianum on root rot disease complex of tomato cv. Hisar Arun (Selection 7) under screen house conditions

\begin{tabular}{|c|c|c|c|c|}
\hline \multirow{2}{*}{ Trichoderma harzianum } & \multicolumn{2}{|c|}{${ }^{*}$ Per cent disease incidence } & \multirow{2}{*}{$\begin{array}{c}\text { Total } \\
\text { mortality (\%) }\end{array}$} & \multirow{2}{*}{$\begin{array}{c}\text { Disease } \\
\text { control (\%) }\end{array}$} \\
\hline & ${ }^{1}$ PEM (\%) & ${ }^{2}$ POEM (\%) & & \\
\hline $5 \mathrm{~g} / \mathrm{kg}$ soil & $16.7(23.8)$ & $33.3(35.2)$ & 50.0 & 21.0 \\
\hline $10 \mathrm{~g} / \mathrm{kg}$ soil & $10.0(18.4)$ & $26.7(31.0)$ & 36.7 & 42.0 \\
\hline $\begin{array}{l}\text { Check } 1 \text { ( } R \text {. solani and } M \text {. javanica } \\
\text { inoculated simultaneously) }\end{array}$ & $23.3(28.8)$ & $40.0(39.2)$ & 63.3 & 0.00 \\
\hline Check 2 (No pathogen) & $0.0(4.05)$ & $0.0(4.05)$ & - & - \\
\hline CD at $5 \%$ & $(5.79)$ & $(4.9$ & - & - \\
\hline $\mathrm{CV}$ & $(16.1)$ & (9.5) & & \\
\hline $\operatorname{SE}(m)$ & $(1.7)$ & $(1.5)$ & & \\
\hline
\end{tabular}


A Non-chemical Approach to the Management of Root Rot Disease Complex of Tomato Concomitantly Caused by Rhizoctonia...

Table 4: Effect of seed dressing of different fungicides on root rot disease complex of tomato cv. Hisar Arun (Selection 7) under screen house conditions

\begin{tabular}{|c|c|c|c|c|}
\hline \multirow{2}{*}{ Fungicides } & \multicolumn{2}{|c|}{${ }^{*}$ Disease incidence } & \multirow{2}{*}{$\begin{array}{c}\text { Total } \\
\text { mortality }(\%)\end{array}$} & \multirow{2}{*}{$\begin{array}{l}\text { Disease } \\
\text { control }(\%)\end{array}$} \\
\hline & PEM & POEM & & \\
\hline Carbendazim 50WP & $13.3(21.1)$ & $20.0(26.6)$ & 33.3 & 47.4 \\
\hline Captan 50 WP & $16.7(23.9)$ & $30.0(33.2)$ & 46.7 & 26.2 \\
\hline Thiram 75WP & $20.0(26.6)$ & $23.3(28.8)$ & 43.3 & 31.6 \\
\hline Mancozeb 75WP & $23.3(28.8)$ & $33.3(35.2)$ & 56.6 & 10.6 \\
\hline Carboxin 37.5WP + Thiram 37.5 WP & $13.3(21.1)$ & $23.3(28.8)$ & 36.6 & 42.2 \\
\hline $\begin{array}{l}\text { Check-1 ( } R \text {. solani and } M . \text { javanica } \\
\text { inoculated simultaneously) }\end{array}$ & $23.3(28.8)$ & $40.0(39.2)$ & 63.3 & 0.0 \\
\hline Check (No pathogen) & $0.0(4.05)$ & $0.0(4.05)$ & 0.0 & - \\
\hline CD at $5 \%$ & $(6.6)$ & $(4.0)$ & - & - \\
\hline CV & $(16.7)$ & $(8,7)$ & & \\
\hline $\mathrm{SE}(\mathrm{m})$ & $(2.1)$ & (1.4) & & \\
\hline
\end{tabular}

emergence plant mortality observed between Captan 50 WP (16.7\%) and Carboxin 37.5WP + Thiram 37.5WP (13.3\%) but post-emergence planmortality was significantly less in Carboxin 37.5WP + Thiram 37.5WP (23.3\%) seed dressing as compared to Captan 50WP seed dressing (30\%). The experimental results regarding disease management of root rot disease complex with Carbendazim were in agreement of the results of Emad Abd (2015) and Devi et al. (2016) who observed Carbendazim as the most effective seed dressing fungicide which effectively reduced the pre and post emergence mortality of seedlings caused by $R$. solani.

\section{CONCLUSION}

The results of present study indicate that application of organic amendments and biocontrol agents significantly reduced the root rot complex disease of tomato caused by concomitant occurrence of $R$. solani and $M$. javanica which can further be exploited along with chemical control for suitable integrated disease management.

\section{REFERENCES}

Abo-Korah, M.S. (2017). Biological Control of Root-Knot Nematode, Meloidogyne javanica Infecting Ground Cherry, Using Two Nematophagous and Mychorrhizal Fungi. Egyptian Journal of Biological Pest Control. 27(1): 111-115.

Abuzar, S. (2013). Antagonistic effects of some fluorescent Pseudomonas strains against root rot fungi (Rhizoctonia solani and Fusarium oxysporum) and root-knot nematodes (Meloidogyne incognita) on chili (Capsicum annum). World Applied Sciences Journal. 27(11): 1455-1460.

Archana, N. and Shweta, B. (2014). Management of Rhizoctonia solani by using antagonist, botanicals and essential oils. The Bioscan. 9(3): 1317-1321.

Borah, A., Baruah, A. and Gogoi, D. (2018). Management of Meloidogyne incognita and Rhizoctonia solani disease complex with fungal antagonist in tea seedling. Indian Journal of Nematology. 48(1): 30-35.
Choudhary, A. and Ashraf, S. (2019). Utilizing the combined antifungal potential of Trichoderma spp. and organic amendments against dry root rot of mungbean. Egyptian Journal of Biological Pest Control. 29(1): 1-8.

Cohen, M.F., Yamasaki, H. and Mazzola, M. (2005). Brassica napus seed meal soil amendment modifies microbial community structure, nitric oxide production and incidence of Rhizoctonia root rot. Soil Biology and Biochemistry. 37(7): 1215-1227.

Devi, T.S., Mahanta, B. and Borah, A. (2016). Comparative efficacy of Glomus fasciculatum, Trichoderma harzianum, carbofuran and carbendazim in management of Meloidogyne incognita and Rhizoctonia solani disease complex on brinjal. Indian Journal of Nematology. 46(2): 161-164.

El-Nagdi, W.M.A. and Abd-El-Khair, H. (2008). Biological control of Meloidogyne incognita and Rhizoctonia solani in eggplant. Nematologia Mediterranea. 36(1): 85-92.

Emad Abd, A. (2015). Studies on Root Rot of Tomato (Solanum lycopersicum Mill.) caused by Rhizoctonia solani Kuhn. Ph.D. Thesis, University of Agricultural Sciences GKVK, Bangalore. $76 \mathrm{pp}$.

Gerdemann, J.W. and Nicolson, T.H. (1963). Spores of mycorrhizal Endogone species extracted from soil by wet sieving and decanting. Transactions of the British Mycological Society. 46(2): 235-244.

https://www.hau.ac.in/page/o-p-stat

Kareem, T.A. and Hassan, M.S. (2014). Evaluation of Glomus mosseae as biocontrol agents against Rhizoctonia solani on tomato. Journal of Biology, Agriculture and Healthcare. 4(2): 15-19.

Kumar, V. and Haseeb, A. (2009). Interactive effect of Meloidogyne incognita and Rhizoctonia solani on the growth and yield of tomato. Indian Journal of Nematology 39: 387-388.

Mukhopadhyay, A.N., Brahmbhatt, A.B. and Patel, G.I. (1986). Trichoderma harzianum A potential biocontrol agent for tobacco damping-off. Tobacco Research. 12: 26-35.

Parveen, G., Mukhtar, N. and Sheikh, M.K. (2019). Enhancement of growth and suppressing the root diseases of tomato plant by using organic amendment. Pure and Applied Biology (PAB). 8(2): 1092-1099. 
A Non-chemical Approach to the Management of Root Rot Disease Complex of Tomato Concomitantly Caused by Rhizoctonia...

Rizvi, R., Ansari, R.A., Iqbal, A., Ansari, S., Sumbul, A., Mahmood, I. and Tiyagi, S.A. (2015 a). Dynamic role of organic matter and bioagent for the management of Meloidogyne incognita-Rhizoctonia solani disease complex on tomato in relation to some growth attributes. Cogent Food and Agriculture. 1(1): 1068523.

Rizvi, R., Singh, G., Safiuddin, Ali Ansari, R., Ali Tiyagi, S. and Mahmood, I. (2015 b). Sustainable management of rootknot disease of tomato by neem cake and Glomus fasciculatum. Cogent Food and Agriculture. (1): 1008859.
Shafique, H.A., Sultana, V., Ara, J., Ehteshamul-Haque, S. and Athar, M. (2015). Role of antagonistic microorganisms and organic amendment in stimulating the defense system of okra against root rotting fungi. Polish Journal of Microbiology. 64(2): 157-162.

Singh, N., Singh, A., Sharma, M.C. and Goswami, B.K. (2015). Performance of a highly potent strain of Trichoderma harzianum possessing egg parasitic character against root knot nematode in addition to mycoparasitism isolated from vegetable growing areas of northern India. Plant Archives. 15(2): 667-670.

www. indiastat.com/table/agriculture-data/2/horticulture/118/1201726 /data.aspx. 